\title{
Recognition of Foreign Relationships Under the Civil Partnership Act 2004
}

\section{Introduction}

The United Kingdom's Civil Partnership Act 2004 came into effect on $5^{\text {th }}$ December 2005, having received Royal Assent just over a year previously. It creates an institution for same-sex couples, known as "civil partnership", parallel to but separate from marriage, and it replicates most of the rules of civil marriage in terms of entry, consequences during subsistence, and termination. Opposite-sex couples have no access to this new institution, just as same-sex couples have no access in the UK to the established institution of marriage. Maintaining the exclusivity of both institutions to the different gender mixes was crucial to the Government's policy in promoting the legislation, designed to avoid the criticism that the Act represented an attack on the institution of marriage ${ }^{1}$. The United Kingdom was by no means the first country to introduce civil partnership for same-sex couples: the credit goes to Denmark $^{2}$, though that country was quickly followed in the 1990s by the other Scandinavian countries and in the early 2000s by an increasing number of western and central European countries. ${ }^{3}$ In addition, civil partnership has been introduced, by a variety of names (the most common of which are "civil union" and "registered partnership") in other (politically) western jurisdictions, such as some provinces and states in North America ${ }^{4}$, and New Zealand. ${ }^{5}$

\footnotetext{
${ }^{1}$ See Civil Partnership: A Framework for the Legal Recognition of Same-Sex Couples (DTI, 2003) at paras 2.7 - 2.8 and Annex B; Civil Partnership Registration: A Legal Status for Committed Same-Sex Couples in Scotland (Scottish Executive 2003) at paras 5.7 - 5.8. ${ }^{2}$ Act No 372, Act of Registered Partnerships, $7^{\text {th }}$ June 1989. For English language discussion see L. Nielsen "Family Rights and the 'Registered Partnership' in Denmark" (1990) 4 Int J Law and Fam 297; M Broberg "The Registered Partnership for Same-sex Couples in Denmark" (1996) 8 Ch \& Fam LQ 149; I. Lund-Andersen "The Danish Registered Partnership Act 1989: Has the Act Meant a Change in Attitudes?" in R Wintemute \& M Andenaes (eds) Legal Recognition of Same-Sex Partnerships (Hart, 2001) at pp $417-426$.

${ }^{3}$ For a comparative study of nine European countries, see K Waaldijk (ed) More or Less Together: Levels of Legal Consequences of Marriage, Cohabitation and Registered Partnership for Different-Sex and Same-Sex Partners, INED, Paris 2005. See http://wwwsame-sex.ined.fr.

${ }^{4} A$ valuable review of the US situation may be found in $L$ Silberman "Same-Sex Marriage: Refining the Conflict of Laws Analysis" (2005) U Penn LR 2195.

${ }^{5}$ For New Zealand, see the Civil Union Act 2004 , no 102 (13 ${ }^{\text {th }}$ December 2004) (NZ). One interesting difference between the UK and the New Zealand approach is in language. In the UK, in what is probably another attempt to distance the new institution from marriage, the Act
} 
Further, a small but increasing number of countries - the Netherlands, Belgium, Spain, Canada and the state of Massachusetts in the USA - have opened up the existing institution of marriage to same-sex couples. Whether through marriage or civil partnership, then, same-sex couples in an increasing number of western countries have the means to have their relationship institutionalised by the state and recognised by the law.

Given the mobility of the population in western countries the invention of civil partnership gave rise almost immediately to the question of foreign recognition ${ }^{6}$ and there is little doubt that UK courts will eventually face virtually all the questions of recognition of foreign civil partnerships that they have been facing in relation to marriage these two hundred years. The 2004 Act anticipated this and makes extensive provision for private international law issues arising from civil partnership registered both here and abroad ${ }^{7}$. It is the purpose of this article (i) to examine the UK statutory provisions relating to recognition of foreign relationships in order to see how they will operate in practice, (ii) to explore various questions to which the 2004 Act gives no ready

talks about civil partnerships being "registered" (Civil Partnership Act 1004, ss 2, 85 and 137) while the New Zealand Act talks of civil unions being "solemnised" (after which, like marriages, they are then registered): Civil Union Act 2004, s 14.

${ }^{6} \mathrm{I}$ am unaware of any discussion of private international law issues relating to same-sex couples earlier than my own "Reproductive Technologies, Transsexualism and Homosexuality: New Problems for International Private Law" (1994) 43 ICLQ 757 where I suggested that Danish registered partnerships affected status in exactly the same way as marriage did and that therefore the marriage recognition rules had to apply without qualification. This was supported by J Murphy in "The Recognition of Same-Sex Families in Britain: The Role of Private International Law" (2002) 16 Int. J. Law Pol \& Fam 181. I returned to the issue in a rather narrower context in "Would Scots Law Recognise a Dutch Same-Sex Marriage?" (2003) 7 Edin. LR 147, the analysis in which is as we will see only partly superseded by the Civil Partnership Act 2004. See also Fiorini, "New Belgian Law on Same-Sex Marriages and its Private International Law Implications" (2003) 52 ICLQ 1039. The matter has been discussed rather more extensively in the North American literature: see for example T Keane, "Aloha, Marriage? Choice of Law Arguments for Recognition of SameSex Marriages" (1995) 47 Stan LR 499; Note, "Conflict of Laws and the Recognition of SameSex Marriages" (1996) 109 Harv LR 2038; L Kramer, "Same-Sex Marriage, Conflict of Laws and Public Policy" (1997) 106 Yale LJ 1965; A Griffin, "Another Case, Another Clause Same-Sex Marriage, Full Faith and Credit and the US Supreme Court's Evolving Gay Rights Agenda" [1997] PL 315; L Silberman, op cit $n$. 4. This literature, and the US case law (see for example Rosengarten v. Downes 71 Conn App 372 (2002) (no jurisdiction in Connecticut to dissolve a Vermont civil union) and Lane v. Albanese 2005 WL 896129 (no jurisdiction in Connecticut to dissolve a Massachusetts same-sex marriage)) is stimulating but provides little real help in predicting how the private international law rules in the UK's Civil Partnership Act 2004 will be applied by the courts because the US analysis is nearly always intra-state rather than international and the major issue tends to be constitutional, as the works of Kramer and Griffin, above, show.

${ }^{7}$ Civil Partnership Act 2004, part 5. 
answer and, crucially, (iii) to assess the extent to which the private international law rules relating to civil partnership, insofar as they differ from those of marriage, might be argued to be for that reason inconsistent with the non-discrimination provisions in the European Convention on Human Rights $(E C H R$ ). The institution of civil partnership engages art 8 of the ECHR (right to respect for family life) and, given that discrimination between couples on the basis of gender mix has been held by the European Court to be analogous to discrimination between individuals based on sex or sexual orientation $^{8}$, art 14 therefore requires that there be shown to be a rational and proportionate reason for treating the two types of couple differently. The assumption made throughout is that the purpose of the 2004 Act is to put same-sex registered couples in the same position as opposite-sex registered (i.e. married) couples, except to the extent to which it would be inappropriate to do $\mathrm{so}^{9}$. The claims of the lesbian, gay, bisexual and transgender (LGBT) community, including those of same-sex couples, for equality and to be free from unjustified discrimination are as strong in private international law as they are in relation to domestic rules of law. This is not, however, a plea for identical rules (for I accept without reservation that some marriage rules are not appropriate for civil partnership) but a working premise that if the private international law rules for civil partnership are indeed different from those for marriage, there needs to be a good reason to justify the difference.

This article does not attempt an analysis of all the private international law provisions in the 2004 Act. Outwith its remit are the sections relating to the recognition of overseas dissolutions (which follow, virtually identically, the rules for recognition of overseas divorces ${ }^{10}$ ) and the more complex rules of jurisdiction. The latter issue may well be at least as important (in practical terms) as those considered here, but an examination of its specialties will need to wait another day. Recognition of the existence of the relationship itself is logically anterior to either of these issues and the way the 2004 Act

\footnotetext{
${ }^{8}$ Karner v. Austria [2003] 2 FLR 623. See n 110 below and text thereto.

${ }^{9}$ For example the non-extension to civil partnership of the organ-specific concepts of impotency (the sole ground in Scots law for holding a marriage to be voidable), consummation (lack of which leaves a marriage in England and Wales voidable) and adultery. Presumptions of paternity based on marriage are also inappropriate for civil partnership.

${ }^{10}$ See $n 113$ below.
} 
deals with this recognition generates sufficient complexities to justify the limited examination offered here.

\section{PART ONE: THE GENERAL RECOGNITION RULE}

\section{What is it that is Being Recognised?}

Though the concept of marriage takes on many guises across the world, it has long been assumed that every country in the world (i) has the legal institution of marriage in one form or another and (ii) knows what marriage in other countries is. These assumptions, though questionable, ${ }^{11}$ render it unnecessary for the private international law rules of recognition of marriage to define the types of institutions that might be recognised, or to list the countries whose marriages are open to recognition. Neither assumption, however, holds good with foreign civil partnerships, which exist in what is still a fairly small minority of the world's states and which, in that small minority, take a wide variety of forms. So the Civil Partnership Act 2004, before providing recognition rules, delimits, through the concept of "overseas relationships", the types of foreign domestic relations that are open to recognition through application of these rules. ${ }^{12}$ The definition of "overseas relationships", contained in s 212(1), is in two (cumulative) parts.

The first part of the definition concerns relationships in general. To be an "overseas relationship" the relationship must either be one of the specified relationships or, if not specified, it must meet the "general conditions"13. The "specified relationships" are listed in schedule 20 to the Act and include, for example, civil unions from Vermont, Connecticut and Quebec, domestic

\footnotetext{
${ }^{11}$ Sometimes the court has to determine whether the relationship before it is one of "marriage" to which the marriage recognition rules can apply, as most commonly with polygamous marriages, and also with institutions like concubinage which some countries recognise. In Nachimson v. Nachimson [1930] P 217 the question was whether a relationship that could be ended at will was to be regarded as a marriage, which is a "union for life". (The question was answered in the affirmative).

${ }^{12}$ A precedent for this approach may be found in relation to "overseas adoptions" which, to be eligible for recognition, must come within the terms of the Adoption (Designation of Overseas Adoptions) Order 1973, SI 1973 No 19.

${ }^{13} 2004$ Act, s 212(1)(a).
} 
partnerships from California, Maine and Massachusetts, registered partnerships from Denmark, Finland, Norway, Sweden and the Netherlands, Lebenspartnerschaften from Germany, pactes civile de solidarité (PaCS) from France, and same-sex marriages ${ }^{14}$ from Belgium, the Netherlands, Spain and Canada. The Secretary of State has the power to amend the list in schedule 20 by adding a relationship, removing a relationship or amending the description of a relationship. ${ }^{15}$ If the relationship is not one of those explicitly specified then it will nevertheless be within the definition of "overseas relationship" if it meets "the general conditions". These conditions are that, under the relevant law, (i) the relationship may not be entered into if either of the parties is already a party to a relationship of that kind or is lawfully married, (ii) the relationship is of indeterminate duration and (iii) the effect of entering the relationship is that the parties are treated as a couple either generally or for specified purposes or are treated as married ${ }^{16}$. This provision is designed both to take account of the variety of forms that domestic relationships can take and to allow foreign changes of law to be recognised even before the Secretary of State has been able to react thereto ${ }^{17}$. The aim is clearly to cover as many foreign relationships as possible, but there are likely to be many areas of doubt. For example, in some countries couples who are not married can access some of the rights and responsibilities of marriage by registering their cohabitation ${ }^{18}$. Such couples are likely to be covered because they would be "treated as a couple ... for specified purposes". Other countries (including, incidentally, the United Kingdom ${ }^{19}$ ) permit some marriage-like consequences to cohabitants but do not provide a

\footnotetext{
${ }^{14}$ The approach of the Act is to convert foreign same-sex marriages into domestic civil partnerships: the effect of so doing is described in Part III below.

${ }^{15} 2004$ Act, s 213(2).

${ }^{16} 2004$ Act, s 214

${ }^{17}$ In the year between the passing of the Act and its coming into force, the number of jurisdictions introducing civil partnership almost doubled. The most recent amendment to sched 20 is contained in the Civil Partnership Act 2004 (Overseas Relationships) Order 2005, SI 2005/3135 (November 11, 2005) which adds Andorra and Tasmania to the list of jurisdictions whose registered same-sex relationships are "specified" for the purpose of $\mathrm{s}$ 212(1)(a).

${ }^{18}$ Many states in the USA, for example, have enacted "Reciprocal Benefits Acts" designed to be far less than marriage or civil partnership but with a variety of important legal consequences. As representative, see Act Relating to Unmarried Couples 1997, Act 383, Hawaii.

${ }^{19}$ See for example the Fatal Accidents Act 1976, the Housing Act 1988, and the Social Security Contributions and Benefits Act 1992.
} 
mechanism whereby the non-marital cohabitation can be registered. In New South Wales, for example, extensive property rights can be claimed by cohabitants (in what are there called "de facto relationships"), opposite-sex and same-sex: cohabitants in that state are "treated as a couple" for the purposes of, for example, financial provision on separation or on death ${ }^{20}$. The requirement to satisfy the general conditions is designed to ensure that the only relationships open to recognition are monogamous, indefinite relationships which have at least some of the legal consequences of marriage.

The second part of the definition of "overseas relationships" concerns individual relationships which belong to a type that has satisfied the first part of the definition. The individual relationship must (i) be registered with a responsible authority, (ii) be between two people of the same sex and (iii) be between two people neither of whom is presently married or in a civil partnership. $^{21}$ The first condition will ensure that only institutionalised relationships are recognised: so for example unregistered cohabitations on the New South Wales model, however extensive the legal consequences thereof, are not open to recognition as civil partnerships under the Act. The second condition ensures that in no circumstances can a relationship be recognised under the Act if the parties are of the opposite sex: this rule, reflecting the UK domestic rule, is likely to create substantial complexity in the application of the 2004 Act and is discussed further below.

\section{The Grounds for Recognition}

Once a foreign domestic relationship satisfies the definition of "overseas relationship", it will be recognised in the UK and treated here as a civil partnership (to which the UK domestic consequences will apply) if the grounds for recognition set out in s 215 are met. These grounds, described in that section as "the general rule"22, are that under the "relevant law", that is to

\footnotetext{
${ }^{20}$ See the Property (Relationships) Legislation Amendment Act 1999 (NSW).

${ }^{21} 2004$ Act, s 212(1)(b).

22 The general rule is qualified (i) by subsidiary rules when one or both of the parties is domiciled in the UK and (ii) by the same-sex requirement. Both qualifications are discussed below.
} 
say the law of the country or territory where the relationship is registered (including its rules of private international law), ${ }^{23}$ both parties had capacity to enter into the registered relationship and they met all that law's requirements necessary to ensure the formal validity of the relationship. ${ }^{24}$ The place of registration, in other words, governs both formalities and capacity. Now, this may be contrasted with the rules for recognition of foreign marriage which, stated simply, provide that capacity to marry is determined by the antenuptial domicile of each party while the formalities of marriage are governed by the law of the place of celebration (the lex loci celebrationis) ${ }^{25}$. This marriage rule has very recently been given statutory effect in Scotland, ${ }^{26}$ with the addition of a subsidiary rule when the lex loci is Scots law, that a rule of the Scottish internal law which makes a marriage void is to prevail over any law under which the marriage would be valid. ${ }^{27}$ The general rule is clearly different from the rule applying to marriage, but this does not in itself make the position discriminatory in ECHR terms. There must be a difference in effect, and that difference must lack objective justification, before the rule can be said to be discriminatory. Whether the different formulation between recognition of marriage on the one hand and of civil partnership on the other will make a difference in practice depends first upon what is understood by the concept of "capacity" within the context of s 215(1) and secondly on how the private international law rules of the locus operate. "Capacity" in relation to marriage

\footnotetext{
${ }^{23} 2004$ Act s 212(2). Renvoi, in other words, is explicitly part of the rule. ${ }^{24} 2004$ Act s 215(1).

25 See Anton with Beaumont Private International Law (2 ${ }^{\text {nd }}$ edn, 1990) at ch 16 ; Dicey and Morris The Conflict of Laws (13 $3^{\text {th }}$ edn, 2000) at ch 17, Rules 67 and 68; Cheshire and North Private International Law (13th edn 1999) at ch 21; Clarkson and Hill, Jaffey on the Conflict of Laws (1997) ch 8. That this has long been the approach in European jurisdictions is seen in von Bar Private International Law ( $2^{\text {nd }}$ edn, trans. Gillespie, 1892) at pp. 343-351, 358-359. The marriage rule is rather different in the USA where the issue is analysed on an inter-state rather than international basis, with a consequential higher emphasis on the place of celebration, and for that reason the few US cases on recognition of Massachusetts marriages and Vermont civil unions are of little assistance in Europe: see n. 6 above.

${ }^{26}$ Family Law (Scotland) Act 2006, s 38(1) and (2).

${ }^{27} \mathrm{Ibid}, \mathrm{s} 38(3)$. This means that Scots law applies to issues of age, forbidden degrees and capacity to and validity of consent for all marriages celebrated in Scotland. The same result is achieved with civil partnership by s 86(1) of the Civil Partnership Act 2004, which provides that two people (implicitly, no matter what their personal law says) are not eligible to register a civil partnership in Scotland unless the Scottish rules on these (and other) matters are satisfied. This reflects the English provision for civil partnership in s. 3, but there is not so clear a rule in English marriage law: on the role of the lex loci in questions of essential validity, see Cheshire \& North $\left(13^{\text {th }}\right.$ edn) at pp 731-733. The significance of the change of terminology from "capacity" to marry to "eligibility" to enter a civil partnership is discussed below.
} 
is often differentiated in the literature from issues of consent and is limited to issues like age, forbidden degrees, and prior relationships. ${ }^{28}$ This differentiation makes some sense in English law where lack of consent does not absolutely nullify a marriage (as incapacity would), but it makes little sense in Scots law where invalid consent does invalidate the marriage and consent, therefore, is logically seen as a part of capacity. ${ }^{29}$ In any case, in relation to civil partnership, since both "capacity" and "formal validity" are referred to the law of the place of registration, we must interpret this to mean that every aspect of validity of a civil partnership is either one or the other for no rule is given for any other aspect of validity and it may be assumed that the Act is designed to be comprehensive. Put simply, the general rule is that all matters of validity of a civil partnership are referred to the law of the place of registration (including that system's rules of private international law). Clearly, this differs from marriage, where the rule is that formalities but not capacity are referred to the lex loci, but whether that creates a difference in effect will depend upon the private international law rules adopted by the law of the place of registration, as can be seen by considering the application of the rules in practice.

\section{Scenario One}

A Dutch man registers in the Netherlands his partnership with a man of different nationality. To be recognised in the UK, Dutch formalities must be followed (exactly as if an opposite-sex couple were marrying in the Netherlands). But unlike marriage the question of capacity to enter a civil partnership is also referred to Dutch law as the lex loci. However, often this different rule will not lead to different results, because the "relevant law" (the lex loci) is expressly defined to include that country's rules of private international law. So if the lex loci (Dutch private international law, in our example) refers the issue of capacity to the parties' personal law, then by renvoi the same result would be

\footnotetext{
${ }^{28}$ See for example Cheshire and North, $13^{\text {th }}$ edn at 721 ; Dicey \& Morris $13^{\text {th }}$ edn $(2000)$ at 671 and 688; Jaffey (1997) at 307.

${ }^{29}$ Anton and Beaumont, n 25 above, at 439-444; Clive Husband and Wife $4^{\text {th }}$ edn at 133. And see Singh v. Singh 2005 SLT 749 where it was held that validity of consent was a matter to be determined by the law of the domicile. This again locates consent within the parameters of capacity.
} 
achieved for civil partnership as is achieved with the marriage rule which refers to personal law directly. However, the Netherlands in fact follows the UK approach of applying its own domestic rules of capacity (eligibility) to all civil partnerships in the Netherlands ${ }^{30}$ with the result that Dutch capacity rules apply to both parties. The Dutch private international law rule for marriage is that either Dutch law or the personal law must be satisfied, which is clearly more generous than the civil partnership rule. But this will lead to a marriage being recognised where a civil partnership would be refused recognition only when the domestic rule of the Netherlands is less generous than the domestic rule of the personal law.

\section{Scenario Two}

Two women, aged 16 and 19, register a civil union in New Zealand, where the age of both marriage and civil union is $16^{31}$. UK law will recognise this relationship as a valid civil partnership if the relevant law (the law of New Zealand) is satisfied on both formalities and capacity. If New Zealand private international law kept the matter of capacity or incapacity through nonage to itself as the lex loci (as both Dutch and UK law does) then the civil union would be recognised in the UK because both parties are (ex hypothesi) of full age in New Zealand: there is no difference here between marriage and civil partnership. If, however, one of the women is a New Zealand national and the other is (say) Dutch and New Zealand private international law refers the matter to the parties' personal law ${ }^{32}$ then the civil union would be valid in New Zealand only so long as it is the younger who is the New Zealander (and so capable by her personal law) and the elder who is Dutch (and capable by her personal law): in these circumstances the relationship would be recognised as a civil partnership in the UK, just

\footnotetext{
${ }^{30}$ See the Dutch Act of 6 July 2004 on Private International Law, published in Staatsblad 15 July 2004, nr. 334.

${ }^{31}$ Civil Union Act 2004 (NZ), s.7

${ }^{32}$ With studied ambiguity the Civil Union Act 2004 merely provides (through an amendment to the Family Proceedings Act 1980, s 31(2)) that nothing in the legislation shall affect the law as to the validity in New Zealand of a marriage or civil union that is not governed by the law of New Zealand.
} 
as a marriage in these circumstances would be. However, if it is the younger party who is from the Netherlands (where the age of marriage and civil partnership is 18) and New Zealand private international law refers the matter of capacity (eligibility to enter a civil partnership in New Zealand) to the personal law of each party, then the relationship would not be recognised in the UK because to apply the relevant law (New Zealand law, including its rules of private international law) would refer the matter to each party's personal law, by which the younger woman did not have capacity to register. Again this would be the same result as in the case of marriage.

It follows that referring issues of capacity to the lex loci as opposed to the ante-nuptial domicile will give different results vis-à-vis marriage and civil partnership only when the domestic rules of the locus are different for the two institutions. But it would be the same if issues of capacity were referred by UK choice of law rules to the ante-registration domicile: that law may or may not treat capacity to enter a civil partnership differently from capacity to enter a marriage. This means that the rule in the Civil Partnership Act 2004, while it may lead to a different result for marriage, does so by no different mechanism than the marriage rule (i.e. the acceptance of a foreign rule of law). Both the marriage rule and the civil partnership rule permit a role to foreign private international law rules which may themselves refer to a discriminatory domestic rule and this is not in itself a basis for refusing to accept the result.

\section{Relationships with UK Connection: Parties Domiciled in UK}

Different considerations arise if one of the parties to an overseas relationship is domiciled in any part of the United Kingdom, for in that case certain extra requirements need to be satisfied beyond "the general rule" before the relationship will be recognised here. Section 217 provides that if the overseas relationship has been registered abroad at a time when one or both of the parties was domiciled in England and Wales or Northern Ireland then the two people concerned are not to be treated as having formed a civil partnership if at the time of registration either of them is under 16 years of age, or they are within the forbidden degrees of relationship specified by English or Northern 
Irish law ${ }^{33}$. If one or both of the parties is domiciled in Scotland, then the same conditions apply and in addition the relationship will not be treated as a civil partnership if either is incapable of understanding the nature of civil partnership or of validly consenting to its formation. ${ }^{34}$ The effect of this is to import the stated aspects of capacity from the law of the domicile (if in the UK) as well as the law of the place of registration.

\section{Scenario Three}

Two women, aged 15 and 19, register a civil partnership in Spain (where the age of marriage and civil partnership is 14). If the 15-yearold is domiciled in a UK jurisdiction this overseas relationship would not be entitled to recognition in the UK because of $s 217(2)(a)$. This is the same as with marriage. ${ }^{35}$ However, the same result follows if it is the British girl who is 19 (and so capable by her personal law) and the Spanish girl who is 15 (and capable by her personal law), and both have capacity by the law of the place of registration. This overseas relationship would not be treated as a civil partnership in the UK, because the effect of $s 217(2)(a)$ is that if either is domiciled in the UK,

\footnotetext{
${ }^{33} 2004$ Act, s 217(2) and (6).

${ }^{34} 2004$ Act, s 217(4). This additional requirement is necessary in the Scottish provisions since lack of valid consent in Scotland will render the civil partnership void while in England and Wales and in Northern Ireland, following the marriage rule (and to the bemusement of lawyers in Scotland), it merely renders the civil partnership voidable: 2004 Act, ss 50(1)(a) and 174(1)(a). The stark difference between English and Scots law on this point can be illustrated by comparing Kaur v. Singh [1981] Fam L 152 where the English Court of Appeal rejected a petition for nullity of a marriage that parents had forced their son to enter into, with Singh v. Singh 2005 SLT 749 where the Scottish Court of Session followed a long line of similar cases (including Mahmud v. Mahmud 1994 SLT 599 where the facts are very much on a par with those in the English case) and granted the petition on the basis that there had been no true consent.

${ }^{35}$ See the Marriage Act 1949, s 2, which provides the age limit for marriages solemnised in England and Wales and is assumed to impose an incapacity on all persons domiciled there (because it is a re-enactment of the Age of Marriage Act 1929). See also the Matrimonial Causes Act 1973, s 11(a)(ii), though that is less clearly a rule of capacity since it provides as one of the grounds upon which a marriage will be void that either of the parties is under 16. The Scottish equivalent, s 1(1) of the Marriage (Scotland) Act 1977, is much clearer to the effect that this is a matter of capacity attaching to all persons domiciled in Scotland and applying wherever in the world the marriage takes place. But, crucially, there is no equivalent in Scotland to s 11(a)(ii) of the 1973 Act. The same ambiguity is replicated for English law, and avoided for Scots law, in the Civil Partnership Act 2004. Section 3, in the English part, imposes an age limit to registration as civil partners; section 86, in the Scottish part, imposes an age limit to registration in Scotland as civil partners.
} 
both need to be of an age that they could enter into a civil partnership in the UK (even when the partnership is actually created abroad). ${ }^{36}$

Now, English lawyers will not find this result particularly surprising as it is simply a statutory application of the English rule applicable to marriage: the rule in Pugh v. Pugh ${ }^{37}$ is that a marriage abroad involving a party domiciled in England is invalid if either of the parties is not of the English age of marriage. But Scots marriage law does not follow Pugh v. Pugh ${ }^{38}$ and so the application to civil partnership of the rule in Pugh creates a difference between marriage and civil partnership in that jurisdiction. A 19 year old Scottish domiciliary may marry abroad a 15 year old, so long as the 15 year old has personal capacity and the place of celebration permits this. ${ }^{39}$ But a 19 year old Scottish domiciliary who enters into a civil partnership abroad with a 15 year old will not be able to have that relationship treated as a civil partnership in the UK because of the rule in $s 217$. It is difficult to find an explanation why this difference in Scots law between marriage and civil partnership exists, other than as a result of this Scottish family law matter being dealt with by the Westminster Parliament which spent far more time on the English than the Scottish provisions. In England the difference does not exist and so the question becomes why the two legal systems have a different approach to marriage. Were Pugh to be overruled in England ${ }^{40}$ it would still leave the explicit rule for civil partnership which, in itself, has little or no justification. Even a policy objective of protecting minors does not explain Pugh since (i) protection is afforded to minors only when one of the parties is an English domiciliary and (ii) in the case itself it was the elderly colonel who was being protected "from the wiles of [a] designing Hungarian teenager". ${ }^{41}$ And in any case the question of validity of marriage (through a challenge to either formalities or capacity) might arise after many years of harmonious conjugal

\footnotetext{
${ }^{36} 2004$ Act, s 217(2)(a), (4) and (6)(a).

${ }^{37}$ [1951] P 482.

${ }^{38}$ Clive Husband and Wife ( $4^{\text {th }}$ edn 1997) at para 09.053; Stair Memorial Encyclopaedia of the Laws of Scotland Child and Family Law (Reissue, 2004) at para 626.

${ }^{39}$ The requirement for both parties to be 16 applies only to marriages solemnised in Scotland: Marriage (Scotland) Act 1977, s 1(2).

${ }^{40}$ For sustained criticism of both the policy behind and the effect of Pugh, see J Murphy, International Dimensions in Family Law (2005) at 91-92.

${ }^{41}$ Morris, Conflict of Laws 6th edn (2005, by D McClean and K Beevers) at para 9.025.
} 
bliss $^{42}$. Were the younger in Scenario 3 to die after 40 years it would be harsh, but seemingly unavoidable, to deny the elder succession rights on intestacy. Protection of minors does not explain this result.

However, it is important to note that the rule in s 217 does not take away the UK domiciliary's capacity to enter into an overseas relationship with a person under the UK age of capacity: the section states no more than that the parties are not to be treated as having formed a civil partnership. There are two consequences to this. First, the overseas relationship will be valid where it is entered into (for the UK Parliament cannot set out rules of eligibility to enter a foreign institution in a foreign country) and the result will be a limping civil partnership - valid in, and having legal effects in, the foreign country where it was registered, but invalid in the UK. And secondly, the refusal to recognise the relationship as a civil partnership under the 2004 Act raises the question of whether it can be recognised as any other form of relationship. If the 19 year old Scotswoman and the 15 year old Spanish woman entered not a civil partnership but into a marriage instead and the 2004 Act does not convert that marriage into a UK civil partnership because of the age of the Spanish woman, does the rule for recognition of marriage (by which the relationship would not be denied recognition in Scotland on the basis of the foreign party's nonage) apply instead? This is the same question, explored more fully later, of recognising the effects of a foreign opposite-sex civil partnership which similarly cannot be treated as a civil partnership here.

\section{Relationships with UK Connection: Registration in the UK}

If the civil partnership is registered in the UK it is not an "overseas relationship" to which the general rule in s 215 applies. Nevertheless, just as validity of overseas relationships is governed by the law of the place of registration, so too both "formation and eligibility" to enter into a civil partnership in the UK are governed by the domestic rules applicable in the

\footnotetext{
${ }^{42}$ As in Brook v. Brook (1861) 9 HLC 193 (11 years) and Berthiaume v. Dastous [1930] AC 79 (13 years).
} 
different jurisdictions in the UK. ${ }^{43}$ Private international law might still be relevant if one or both parties has little or no connection with this country.

\section{Scenario Four}

Two men, Grigory Orlov and Grigory Alexandrovitch Potemkin, are domiciled in and nationals of Russia. They travel to western Europe in order to enter into a civil partnership with each other.

The countries involved in Scenarios 1 - 3 have all themselves had legislation introducing a form of civil partnership into their domestic law. Most countries in the world have not yet done so with the result that same-sex partnerships cannot be registered in such countries. There is something ineluctably artificial in formulating the question in Scenario Four as one of capacity. $\mathrm{Mr}$ and Mrs Brook sought to escape a recognised domiciliary incapacity when they married in Denmark, where marriages between men and their deceased wives' sisters were permitted; but when Messrs Orlov and Potemkin enter a civil partnership in the UK the question of whether Russian law regards them as having the capacity to do so simply does not arise since Russian law knows nothing of civil partnership and so can neither grant nor withhold capacity to enter such an institution (unlike English law in Brook v. Brook ${ }^{44}$ which could grant or withhold capacity to enter an institution that both it and Denmark had). For this reason, the Civil Partnership Act 2004 limits its references to "capacity" to the law of the place of registration (which, of necessity, will have the institution) and, for more general purposes, refers to "eligibility" to enter a civil partnership. ${ }^{45}$ The rules for eligibility to register a civil partnership in the UK are the domestic rules contained in sections 3 (England and Wales), 86 (Scotland) and 138 (Northern Ireland) and there is

\footnotetext{
${ }^{43} 2004$ Act, ss 2-4 (England and Wales), 85-86 (Scotland), and 137-138 (Northern Ireland). 44 (1861) 9 HLC 193.

${ }^{45}$ Eligibility rather than capacity is a useful device for dealing with any institution existing in one country but not another. For example, a couple from a country with no divorce (say, Malta) would be eligible to seek divorce in the UK (so long as jurisdictional rules were satisfied) and the question of capacity by their personal law to seek a change of status simply does not arise (though whether Maltese law would recognise a divorce granted in the UK is, of course, another matter, over which the UK legal system has no control). Eligibility is, in fact, a more apt concept than capacity to describe non-status-based limitations such as forbidden degrees, as opposed to status-based limitations such as age.
} 
no additional prerequisite of domiciliary capacity. So if Messrs Orlov and Potemkin in Scenario Four travel to England, they may register a civil partnership there so long as they are eligible to do so by the English rules of eligibility in s 3 of the 2004 Act. The fact that their relationship would have no effects in the law of their domicile is (notwithstanding that this leads to a limping relationship) irrelevant to the question of its validity within the UK under the 2004 Act. A very different result would be reached if the place of registration were a country like Denmark which limits eligibility to its registered partnerships (but not its marriages) to couples one of whom is resident in or a citizen of Denmark. ${ }^{46}$ If our two Grigories travelled to Denmark, the law of the place of attempted registration would say that they were not eligible to enter into a civil partnership there and, not satisfying local law, any purported registration there would not be recognised here. Rather unexpectedly, then, UK law is (in this respect at least) a little more gay-friendly than the law of the country that invented civil partnership.

\section{Public Policy}

A traditional exception to the recognition of foreign relationships, the public policy exception ${ }^{47}$, is given statutory effect in s 218 of the Civil Partnership Act 2004, under which two people are not to be treated as having formed a civil partnership as a result of having entered into an overseas relationship if it would be manifestly contrary to public policy to recognise the capacity, under the relevant law, of one or both of them to enter into the relationship ${ }^{48}$. This is

\footnotetext{
${ }^{46}$ Act No 372, Act of Registered Partnership, 7 June 1989, art 2(2), as amended by Act No 360, 2 June 1999.

${ }^{47}$ For a discussion within the context of marriage, see TC Hartley "The Policy Basis of the English Conflict of Laws of Marriage" (1972) 35 MLR 571. A more recent sustained examination of public policy within marriage is presented by $\mathrm{J}$ Murphy "Rationality and Cultural Pluralism in the Non-Recognition of Foreign Marriages" (2000) 49 ICLQ 643, where he exposes to light the inherent vagueness of the test. He warns that too ready invocation of public policy can easily be seen in terms of judicial imperialism rather than adherence to some form of universal norm or social value, and that it runs the risk of leading to irrational and inconsistent decision-making.

${ }^{48}$ The Scottish Parliament has recently put the public policy rule in relation to marriage into statutory form, with s 38(4) of the Family Law (Scotland) Act 2006. The wording of this provision is distinctly odd. While the civil partnership formulation allows non-recognition of a capacity otherwise governed by the relevant law, the new Scottish marriage formulation requires non-application of the law of the domicile in determining capacity if it would be contrary to public policy to apply that law. This shifts the focus of public policy from the result of the foreign law to the very choice of the foreign law. But it does not say which system
} 
a sort of safety net to ensure that the heavy reliance on the local law to determine both formalities and capacity ${ }^{49}$ does not require UK courts to recognise a relationship where the rules for capacity are, to our eyes, outrageous $^{50}$ (for example if the age of capacity were set below puberty). As always with public policy it is to be remembered that the exception cannot be invoked just because the law is different, even radically so: it must be obnoxious to the whole legal and social polity of the forum. ${ }^{51}$ While civil partnership is limited to western liberal democracies with (relatively) uniform rules of capacity, the question of applying the public policy exception to foreign capacities presently lies in the realm of the hypothetical, and is likely to remain there for the foreseeable future. The question of whether or not to recognise an incapacity does not arise under the statute, which focuses on domestic rules of "eligibility", but it might be a live issue if reactionary jurisdictions pass legislation purporting to deny their citizens the capacity to enter into legally recognised same-sex relationships anywhere in the world ${ }^{52}$. It is submitted that such legislation cannot have effects in a country like the UK which permits civil partnership: it would be recognising extra-territorial effect of another jurisdiction's rules which are not only different from ours but, arguably, contrary to the important social policy of gender- and sexualityequality that underlies the Civil Partnership Act 2004. We should accept that a relationship entered into here might have no effects in another country, but a person "eligible" by UK rules should be regarded as "capable" and a foreign incapacity based on nothing more than a desire to deny same-sex relationships any legal status should be rejected as contrary to our public

\footnotetext{
determines capacity if the otherwise appropriate law cannot do so and one assumes that Scots law (the lex fori) would apply as a default.

${ }^{49}$ And it is interesting that the public policy exception is limited in its terms to matters of capacity and not matters of form.

50 "Offensive to the conscience of the court", in the words of Simon P in Cheni v. Cheni [1965] $\mathrm{P} 85$ at 99 .

51 "The refusal to recognise foreign law, and rights and status arising from it, is exceptional in Scots law ... In England the proposition gains support from the case of Addison v. Brown [1954] 1 WLR 779" (Anton \& Beaumont, n 25 above at 102). See also Cheshire \& North, n 25 above at 733-734.

${ }^{52}$ In fact the imperative tends to be to protect marriage from the "threat" of same-sexuality and incapacity to enter same-sex marriage is imposed rather than incapacity to enter civil partnership. See as an example the Australian Marriage Amendment Act 2004 which provides that no same-sex relationship can be regarded in Australia as a "marriage": this does not remove capacity (or indeed deny recognition of a foreign relationship as something other than marriage).
} 
policy (exactly as we would have rejected a denial of capacity to enter into a mixed race relationship).

\section{PART TWO: THE SAME-SEX REQUIREMENT}

\section{Introduction}

Though the catalyst for the creation of civil partnership has almost universally been the desire to provide a mechanism whereby access to the rights and subjection to the responsibilities of family life can be extended to same-sex couples, some legal systems, including Belgium, the Netherlands, France and New Zealand, have extended the availability of their version of the new institution to opposite-sex couples also, on the ground of choice. ${ }^{53}$ This is quite contrary to the approach in the UK, where the Civil Partnership Act 2004 takes great pains to limit access to British civil partnerships to couples who are of the same sex as each other. This difference of approach will give rise to at least two problems for UK courts - whether to recognise opposite-sex civil unions entered into abroad, and how to determine gender for the purpose of satisfying the same-sex requirement.

\section{Recognition of Opposite-Sex Civil Partnership Scenario Five}

A man and a woman, who are domiciled in New Zealand, disapprove of marriage but register their relationship there as a civil union. They move to the United Kingdom, but the relationship breaks down. The parties go to a UK court seeking dissolution, for both are seeking to marry other people in this country.

Validity of the civil partnership is a preliminary question to the jurisdiction of the court. ${ }^{54}$ The question here is whether the parties have any relationship at all that a UK court could dissolve, and if so under what provision would the

\footnotetext{
${ }^{53}$ For the European countries, see Waaldijk, n 3 above; for New Zealand, see the Civil Union Act 2004, s4(1).

${ }^{54}$ See, in relation to marriage, A-M v. A-M (Divorce: Jurisdiction: Validity of Marriage) [2001] 2 FLR 6.
} 
court act? These questions might be avoided by the parties (or one of them) simply returning to New Zealand, but that might not be possible in all cases and even it if were it would raise the question of whether there is a legitimate basis upon which opposite-sex civil partners can be obliged to go to that expense when same-sex civil partners can avoid it by accessing what is now their local court. A UK court faced with these questions is unlikely to be able to answer them simply by telling to parties to try another court: the UK forum is not in Scenario Five non conveniens. The matter needs to be dealt with by legal analysis and there are at least six possible approaches that the UK court might adopt in attempting to answer the questions posed above.

First, the UK court might simply conclude that there is no relationship between the parties that can be recognised at all: it is neither opposite-sex marriage nor same-sex civil partnership and the domestic rules, including the dissolution provisions, available to the UK courts are designed for these two forms of conjugal relationship and none other. This, in effect, would be to follow the approach of Lord Penzance in the old case of Hyde v. Hyde where he held that the English court had no jurisdiction to dissolve a polygamous union because the domestic process was designed for monogamous unions only. However, this is an implausible argument in the context of opposite-sex civil partnership, for a number of reasons. First, the Hyde approach proved unsustainable in the long-term. ${ }^{56}$ Secondly, to refuse to recognise an opposite-sex civil partnership as anything at all seems punitive without purpose since there is no obvious basis upon which to regard the couple as any less worthy of recognition than a married opposite-sex couple or a civilly enpartnered same-sex couple. While it might be argued that the denial of civil partnership to opposite-sex couples is necessary to ensure that they choose the institution of marriage when they wish to have their relationship registered with the state, such a political imperative can be legitimate only within the domestic sphere: the UK Parliament and UK courts have no business in protecting the New Zealand institution of marriage in a

\footnotetext{
${ }^{55}$ (1866) LR 1 P\&D 130.

${ }^{56}$ See K Norrie "Would Scots Law Recognise a Dutch Same-Sex Marriage?" (2003) 7 Edin LR 147 at pp $151-154$.
} 
way that the New Zealand Parliament has deliberately rejected. And in any case to refuse all recognition of a New Zealand civil union between an opposite-sex couple would, if the couple had converted from a marriage to a civil union, ${ }^{57}$ amount to UK law holding that a couple who went through a process to change the name but not the status or consequences of their relationship have effectively (and quite contrary to their or their state's intention) divorced (non-judicially). Such a result would be unconscionable and if the divorce analysis is accurate it must be rejected under the authority of $s 51(3)$ (c) of the Family Law Act $1986^{58}$. Thirdly, the approach goes against every policy applicable to the private international law of families certainty, giving effect to the reasonable expectations of the parties, international comity, and avoiding limping relationships. ${ }^{59}$ And fourthly the approach would leave the parties in an unacceptable position, arrived at only by denying the New Zealand relationship while at the same time giving effect to one of its consequences. Remember that the parties are seeking dissolution in order to free themselves to marry other people. But so long as they retain their New Zealand domiciles they will be not free to marry or to enter into a civil partnership anywhere, because their domicile regards them as civilly enpartnered and in UK eyes domiciliary incapacities are carried around the world (subject to s 50 of the Family Law Act 1986) ${ }^{60}$. Ignoring the relationship entirely is the least acceptable approach.

A second option for a court asked to recognise an opposite-sex civil partnership for the purpose of bringing it to an end would be to say that the relationship must be either a civil partnership or a marriage and that since the Civil Partnership Act 2004 prevents it from being treated as a civil partnership

\footnotetext{
${ }^{57}$ Permitted under s 18 of New Zealand's Civil Union Act 2004.

${ }^{58}$ Non-recognition of divorce on the basis that it would be manifestly contrary to public policy to recognise it: I submit it would be manifestly so contrary to separate parties against their wills and intention.

${ }^{59}$ For an examination of the relevant policies, see Hartley n. 47 above.

${ }^{60}$ For Scotland, see the Marriage (Scotland) Act 1977, s 5(4)(f). To enter a second civil partnership both parties must have the status of single person (2004 Act, ss 3(1)(b), 86(1)(d), 138(1)(b) and 212(1)(b)(ii)). That status is determined by the law of the domicile. Of course, the parties might well have acquired a domicile in the UK and lost their New Zealand domicile, but there is no principle of private international law that states that a relationship dissolves through a change of domicile. Wherever the parties are domiciled, New Zealand law at any rate will continue to regard them as enpartnered and not free to repartner.
} 
it must, of necessity, be treated as a marriage (however it is described in the country of its creation). The common law rules on recognition of marriage ${ }^{61}$ would then apply and, if satisfied, the parties in Scenario Five would have access to the divorce court under the applicable divorce legislation. There would, however, be something distinctly odd in the UK court recognising and treating as a marriage a relationship created in a foreign land as an alternative to marriage and entered into by a couple who explicitly rejected the notion of marriage when they formalised their relationship by registering it as something else. Nevertheless, there is some (if slight) authority for an approach such as this. In Lee $v$. $L a u^{62}$ a marriage was held to be potentially polygamous since, by its local law, the husband was entitled to take "secondary wives", or concubines. Concubinage as such is not recognised in any form and so it was treated as a form of marriage, on a par with marriage with the "primary wife", notwithstanding that it would not be so treated by the local law. Here, it may well be tempting for UK courts to treat as a marriage a New Zealand relationship which is not marriage in New Zealand but which nevertheless has all the attributes (except the name) of marriage - including, crucially, the gender mix required for marriage in the UK. But this approach has discriminatory implications. It is to be remembered that treating an oppositesex civil partnership as a marriage would have wider consequences than access to divorce (including use of an extra ground for divorce): it would give them more than they asked for. It would for example entitle the couple jointly to adopt a child in Scotland, notwithstanding that by their own law they would not be married; it would entitle the Scottish court (if one of the parties were domiciled in Scotland) to ignore a flaw in the formalities with ceremonies abroad $^{63}$. The fact that a same-sex civil partnership is not converted into a marriage (or a same-sex marriage treated as a marriage) and awarded these benefits means that the rule becomes necessarily discriminatory on the basis of sexual orientation because its effects, while marriage carries greater benefits than civil partnership, is to preference opposite-sex couples over same-sex couples. There is also a conceptual difficulty with this approach

\footnotetext{
${ }^{61}$ Now statutory in Scotland: Family Law (Scotland) Act 2006, s 38.

62 [1967] P 14.

${ }^{63}$ Family Law (Scotland) Act 2006, s 3(3) and (4). (Various other conditions must, it is admitted, also be satisfied before foreign flaws will be ignored).
} 
which is that, at heart, it is little more than an assertion that state-sanctioned relationships between same-sex couples are, by definition, civil partnerships while state-sanctioned relationships between opposite-sex couples are, by definition, marriage. This may well be the UK approach but the point of private international law is not to insist upon domestic definitions but to give effect, where appropriate, to foreign definitions. This approach, therefore, while it achieves recognition, does so at the cost of principle and needs to be rejected for that reason.

A third approach to the question of recognition of an opposite-sex civil partnership is to accept the reality that the relationship is not a marriage but is in both fact and in (overseas) law a civil partnership. This, however, would seem to be ruled out by the clear terms of s 216(1) of the 2004 Act, which provides that two people are not to be treated as having formed a civil partnership as a result of having registered an overseas relationship if they were not of the same sex under UK law. Whether the failure of UK domestic law to recognise an opposite-sex civil partnership in circumstances in which it would recognise a same-sex civil partnership is inconsistent with the right to respect for family life, as protected by art 8 of the ECHR, is in substance the same question as that arising from the refusal to recognise a foreign samesex marriage (as a marriage) and that question is considered in the final part of this article. In any case, the wording of $s 216(1)$ is so clear that, even if an inconsistency with the ECHR could be found it would not be possible to interpret the provision to mean exactly the reverse of what it says. Even if a declaration of incompatibility were made under s 4 of the Human Rights Act 1998, the recognition question is not answered.

A fourth approach would be to regard the relationship between the parties as essentially contractual with the result that the conflicts rules relating to contract $^{64}$ would apply. But this seems needlessly complex and artificial. The relationship is no more contractual in New Zealand than a same-sex civil union or an opposite-sex marriage; the incidents of marriage and civil

\footnotetext{
${ }^{64}$ Including, for countries in the European Union, those contained in the Rome Convention on the Law Applicable to Contractual Obligations.
} 
partnership are attached (at least in New Zealand); New Zealand law will regard the relationship as one affecting status and its consequences will clearly affect status here - including, as a litmus test, effects of the relationship on capacity to remarry ${ }^{65}$. Murphy ${ }^{66}$ offers a persuasive argument why regarding civil partnerships as mere contracts is misconceived. His most important argument is that freedom to negotiate terms, an important principle in contract, is entirely absent in marriage or civil partnership. A contract analysis to resolve the question of opposite-sex civil partnership must, it is suggested, be rejected.

The fifth approach, and the one preferred here, would be for the courts to develop a non-statutory method of giving effect to the consequences of relationships that cannot be recognised under the statute: the 2004 Act prevents opposite-sex civil partnerships registered abroad from being treated as UK civil partnerships but it does not in its terms prohibit all recognition for all purposes. Indeed, we have already seen that one consequence of the relationship (the imposition of marital incapacity) has to be given effect to in the UK whether or not the relationship itself is recognised. Without treating the relationship formally as either a marriage or a civil partnership the court could fashion appropriate recognition rules, and could do so based on the existing rules for these two separate institutions. The marriage rules themselves had to develop by judicial decision and there is no conceptual reason why common law rules could not be developed judicially for civil partnerships that are not statutory "overseas relationships". In much the same way the courts gave recognition to (or, more correctly, gave effect to some consequences of) polygamous unions without recognising such unions to be "marriages". The recognition rules for marriage and for civil partnership are, in any case, similar in effect, even if structured rather differently in respect to capacity. To fashion a similar rule for relationships not covered by the 2004 Act would not be an illegitimate extension of that Act (even if the same result is reached) but a modification of the existing rule applicable to

\footnotetext{
${ }^{65} \mathrm{~A}$ contractual agreement not to remarry is not, even if not contrary to public policy, capable of affecting a person's status or marital capacity.

${ }^{66}$ n. 40 above at 81-83.
} 
marriage and its extension to the marriage-like (but definitely non-marital) relationship of opposite-sex civil partnership. It would be neither surprising nor unacceptable if the most appropriate formulation of this new judicially developed rule for recognition were to be for all intents and purposes identical to the statutory rules for same-sex civil partnership for, I suggest, oppositesex civil partnership is closer in form and should be closer in effect to samesex civil partnership than to opposite-sex marriage ${ }^{67}$.

A criticism of this approach might be that while it would work easily in the context, say, of succession or determining the existence of a marital incapacity, it is less obviously a suitable solution with the statutory process of dissolution (with which, it will be remembered, statutory intervention was necessary to ensure access to those married polygamously). The relationship must be a marriage before access to the divorce court under the Matrimonial Causes Act 1973 or the Divorce (Scotland) Act 1976 can be granted, and it must be a civil partnership before access to the dissolution court under the Civil Partnership Act 2004 can be granted. If for no other reason, the parties need to know which forms to use. This criticism would appear, however, to be little more than undue legalism if it meant that parties from overseas in a valid conjugal relationship were unable to escape that relationship. It is to be remembered that (other than adultery) the grounds for divorce and dissolution, and the processes, are the same in the UK for marriage and civil partnership and to deny access to the courts for want of an appropriate form and no more substantial reason is, surely, a disproportionate response to those seeking the remedy. Where adultery is not the ground, nothing is lost by allowing opposite-sex civil partners the choice of terminating their relationship by either the Civil Partnership Act 2004 or the Matrimonial Causes Act 1973. The denial to opposite-sex civil partners of the ground of adultery is a cost easily borne: if they wanted that as a possible ground they had the choice (unlike, incidentally, same-sex couples) of getting married.

\footnotetext{
${ }^{67}$ In countries where opposite-sex couples have the choice of marriage or civil partnership, to choose the latter is to positively reject the marital benefits of adoption rights in Scotland and adultery.
} 
There is a sixth solution, mentioned here simply for the sake of completeness, which would give the parties a remedy without requiring the relationship to be recognised as either a marriage or a civil partnership or as anything else. This would be for the parties to seek a declarator of nullity (and with it ancillary relief or financial provision), on the basis that the relationship is of the wrong gender-mix for civil partnership - just as nullity of marriage was declared in Corbett $v$. Corbett ${ }^{68}$ on that same basis. But the 2004 Act does not nullify foreign civil partnerships of the wrong gender mix. The relationship was valid when entered into (unlike the relationship in Corbett) and all the 2004 Act does is to prevent it being treated in the UK as a civil partnership. So some element other than gender mix would be necessary to succeed in an action of nullity. This approach is a dead end.

\section{The Definition of Gender and Transsexual Issues}

The same-sex requirement in the 2004 Act creates another set of problems of some awkwardness, which the Act tries to anticipate but does not fully resolve. These arise from the different approaches in different countries to the question of determining whether or not a couple are of the same gender. Of course this will normally be straightforward but it will not be so if one of the parties is living their life in the gender other than that in which they were apparently born. ${ }^{69}$

Within the private international law provisions of the 2004 Act, the same-sex requirement appears in two separate places. First $s 212$, in defining those "overseas relationships" that are available for recognition, requires that the parties to the relationship must be of the same sex "under the relevant law", that is to say the law of the country or territory where the relationship is registered. ${ }^{70}$ It will be a matter of proof of foreign law whenever a UK court is asked to determine whether an acquired gender is or is not recognised by the foreign legal system. But even if the parties are of the same sex according to

\footnotetext{
${ }^{68}$ [1971] P 83.

69 Different responses to hermaphroditism may well give rise to similar problems but in a (possibly vain) attempt to retain some clarity the present discussion will be limited to the difficulties created by transsexuality.

${ }^{70} 2004$ Act, s 212(1)(b)(i).
} 
the place of registration (and their relationship therefore an "overseas relationship") it will not be treated in the UK as a civil partnership, even if the requirements for recognition in $\mathrm{s} 215$ are otherwise satisfied, if, at the critical time ${ }^{71}$ the parties were not also of the same sex by UK law. This rule, contained in s 216(1), means that the parties must be of the same sex by both the lex loci registrationis and UK law. How UK law determines gender for the purpose of civil partnership is open to some doubt. Marriage is easy, because of authoritative judicial guidance in that context. Gender is initially determined by the rule in Corbett $v$. Corbett ${ }^{72}$ and confirmed in Bellinger v. Bellinger ${ }^{73}$ that biological factors are determining; but since April 2005 the acquisition of a gender recognition certificate under the Gender Recognition Act 2004 will allow a person biologically of one gender to be recognised for most purposes of law, including marriage, as belonging to the other gender. However, such a certificate is available only to persons who are neither married nor in a civil partnership, with the result that marital/civil status must be determined before a gender recognition certificate is applied for. If the applicant is a party to a recognised civil partnership or marriage, only an interim gender recognition certificate may be granted, ${ }^{74}$ the sole effect of which is to provide a ground to dissolve the existing marriage or civil partnership, ${ }^{75}$ so freeing the parties to enter a civil partnership or marriage respectively. But without the certificate a marriage between parties one of whom had changed gender before its celebration is not recognised ${ }^{76}$ and so a full gender recognition certificate may be applied for.

Whether such a certificate is needed in UK law for the purposes of entering into civil partnership here (or recognising a foreign civil partnership) is a much more difficult question. A gender recognition certificate is needed within the context of marriage to get over the biological imperative that lay at the heart of the decisions in Corbett and Bellinger. But there is no biological imperative to

\footnotetext{
${ }_{71}^{71}$ I.e. the time of registration: 2004 Act, s 215(2).

72 [1971] P 83.

73 [2003] UKHL 21.

${ }^{74}$ Gender Recognition Act 2004, s 4(3).

${ }^{75} \mathrm{lbid}$, sched. 2.

${ }^{76}$ Neither is it a civil partnership (Civil Partnership Act 2004, s 216(1)) nor a marriage (Gender Recognition Act 2004, s 21(1) and (2)).
} 
get over with civil partnership, in respect of which procreative potential is selfevidently irrelevant. In another area where procreative potential is irrelevant, equal treatment in employment, the House of Lords (subsequent, be it noted, to Bellinger v. Bellinger) held in A v. Chief Constable, West Yorkshire Police ${ }^{77}$ that a person's acquired gender could be recognised, even without a gender recognition certificate, ${ }^{78}$ in circumstances in which recognition of the new gender furthered rather than inhibited the statutory policy behind the genderspecific rule. Limiting civil partnership to couples of the same sex is a genderspecific rule, and the question becomes whether the purpose of that rule is better served by applying Bellinger (and requiring a gender recognition certificate before the acquired gender is recognised) or applying $A$ v. West Yorkshire Police (and recognising the acquired gender even without a gender recognition certificate). It would appear that there are two purposes to the limiting of civil partnership in the UK to couples of the same sex: (i) to emphasise the difference from marriage, which is opposite-sex, and (ii) to maintain the importance of marriage by denying opposite-sex couples the choice of entering into other legally recognised relationships that are not marriage ${ }^{79}$. The question of whether a civil partnership is available without a gender recognition certificate will not arise very often in the domestic sphere, for a transgendered person wishing to register a civil partnership in the UK with a person of their acquired gender will in practice be advised to obtain a gender recognition certificate first ${ }^{80}$. But in other countries parties will not normally have sought a UK certificate before registering their partnership abroad $^{81}$. If an overseas relationship is entered into by two parties one of whom used to be of the opposite sex to the other but who now lives his or her life and presents to the world as the same sex as the other, and the couple

\footnotetext{
${ }_{78}^{77}$ [2004] UKHL 21.

78 In fact the case was decided before the Gender Recognition Act 2004 was enacted and so no such certificates were available for anyone.

${ }^{79}$ These aims underlie most Government pronouncements on civil partnership: see n. 1 above. A quite different philosophy was adopted by the New Zealand Parliament, which not only permits opposite-sex as well as same-sex civil unions, but also permits married couples to convert their relationship into a civil union and (opposite-sex) civil partners to convert to marriage: Civil Union Act 2004, s 18.

${ }^{80}$ And it may well be that district registrars will refuse to permit registration without such a certificate.

${ }^{81}$ Though in fact they may do so since there is no domiciliary or nationality or residence condition to be fulfilled before making an application to a UK Gender Recognition Panel.
} 
are regarded by the relevant law as a same-sex couple, there is a strong argument to suggest that maintaining the same-sex requirement is furthered rather than inhibited by UK law also recognising the change of sex - for this purpose. If this is so then the reasoning in $A$ v. West Yorkshire Police suggests that a British court could recognise that a person has changed gender in the eyes of UK law, for the purpose of satisfying the same-sex requirement in s 216(1), without requiring that person to seek a UK gender recognition certificate: the court simply needs to be satisfied that the relationship appears for all intents and purposes to be, and to function as, a same-sex relationship.

The 2004 Act, however, assumes that a gender recognition certificate will be sought in such circumstances and makes explicit provision that, when granted, the relationship will be recognised. Section 216(2) neutralises the effect of $s 216(1)^{82}$ by allowing the recognition of the overseas relationship regarded as same-sex by the relevant law but not by UK law, if a gender recognition certification is obtained subsequent to the relationship having been established (as same-sex) abroad. The relationship, now same-sex in both UK law and the foreign law, can be recognised as a civil partnership ${ }^{83}$ and that recognition is retrospective. The very fact that this provision explicitly deals with the conversion, in UK eyes, of an overseas relationship into a same-sex relationship might be taken to imply that this is the only means of recognising a foreign change of gender. But that is to read more into the Civil Partnership Act 2004 (and the Gender Recognition Act 2004) than is actually there. In the domestic sphere, $A$ v. West Yorkshire Police shows us that the Gender Recognition Act 2004 is not the only means by which a change of gender may be given effect to in UK law. To read s 216(2) as imposing a requirement on foreign transsexuals to utilise the Gender Recognition Act would not only deny them opportunities available to UK transsexuals but would also leave some parties in a very unfortunate position because the UK gender recognition process will not always be available.

\footnotetext{
${ }^{82}$ The provision requiring the parties to be of the same sex by UK law.

${ }^{83}$ Unless a valid marriage or civil partnership has been entered into before the acquisition of the gender recognition certificate: s 216(3).
} 


\section{Scenario Six}

A couple in New Zealand enter into a civil union under that country's Civil Union Act 2004, one of them having previously been recognised by New Zealand law as having changed gender. ${ }^{84}$ They move to the UK but the relationship breaks down and they seek dissolution under the Civil Partnership Act 2004.

\section{Scenario Seven}

A couple in New Zealand enter into a civil union under that country's Civil Union Act 2004, one of them having previously been recognised by New Zealand law as having changed gender. ${ }^{85}$ They remain in New Zealand but own immoveable property in the UK; the transgendered partner dies intestate and the other seeks to inherit the UK property under the terms of the Civil Partnership Act 2004 (which gives civil partners succession rights identical to those of spouses $\left.{ }^{86}\right)$.

In both these scenarios, the claim is dependent on the recognition in the UK of the New Zealand civil union, which itself is dependent on the relationship being regarded as same-sex both by New Zealand law and by UK law. If both relationships are regarded by the law of the place of registration as being same-sex relationships, then these New Zealand civil unions are both "overseas relationships" in terms of s 212 (which refers gender to the relevant law $)^{87}$. These overseas relationships satisfy the recognition rules in $s 215$ since (ex hypothesi) the parties had capacity under New Zealand law and met all the formal requirements of New Zealand law. But s 216(1) prevents

\footnotetext{
${ }^{84}$ Permitted, for all purposes including marriage, without official process in New Zealand: Attorney General v. Otahuhu Family Court [1995] 1 NZLR 603.

${ }^{85}$ See $n 84$ above.

${ }^{86}$ Civil Partnership Act 2004, s 71 and sched 4 (England and Wales); s 131 and sched 28 (Scotland); s 195 and sched 14 (Northern Ireland).

87 "Relevant law" being defined in s 212(2) as the law of the place of registration.
} 
recognition in the UK if the parties are not of the same sex under UK law. ${ }^{88}$ Neither couple is same-sex if we assume that the only way in UK law of changing gender is through the mechanism of the Gender Recognition Act. On that assumption, neither relationship is recognised, all four parties are single, and the transgendered party in Scenario Six can seek and acquire ${ }^{89}$ a gender recognition certificate, activating s 216(2) which gives retrospective recognition of the same-sex nature of the relationship and thereby of the relationship itself. In Scenario Six then, the couple, once in possession of a gender recognition certificate, can seek dissolution of their relationship under the Civil Partnership Act 2004. Section 216(2) provides a satisfactory solution.

But this solution works only in its own context. If the assumption that the Gender Recognition Act is the only way of changing gender in the UK is true, then a very different result follows in Scenario Seven, in which a gender recognition certificate is not available - for the simple reason that the transgendered partner is dead and it cannot be sought by anyone else. If the Gender Recognition Act is the only way in UK law of changing gender then the deceased's change of gender can never be recognised, consequently the overseas relationship is not recognised, and the surviving partner will be treated in the UK as a stranger to the deceased and denied any succession rights to UK property. There are two ways of avoiding this unacceptable result. First, we might treat the New Zealand civil union as an opposite-sex civil partnership and seek to recognise it in the way suggested above. Secondly, we could challenge the proposition that the process in the Gender Recognition Act is the only way of changing gender in the UK, on the argument that that Act did not overrule $A$ v. West Yorkshire Police. The first approach would be offensive to the parties and lead to unnecessary gender

\footnotetext{
${ }^{88}$ It is probably not open to argument that the reference to UK law in s 216(1) includes UK private international law, for "relevant law" in s 212 is explicitly stated to include that law's rules of private international law and the omission of a similar inclusion in s 216(1) must be taken to indicate a parliamentary intention to exclude private international law from that section.

${ }^{89}$ One of the grounds upon which a gender recognition certificate will be granted is that the applicant has changed gender under the law of another country: Gender Recognition Act 2004, ss 1(1)(b) and 2(2).
} 
confusion between two legal systems. The second approach is, it is suggested, the more certain and less clumsy way of ensuring that the survivor in Scenario Seven is not disinherited. A v. West Yorkshire Police suggests that a change of gender will be recognised even without a gender recognition certificate if that is the best way of achieving the purpose of the genderspecific rule at issue. The purpose of the same-sex requirement in the Civil Partnership Act is to ensure that civil partnerships look like and function as same-sex relationships as opposed to opposite-sex relationships. It is not (and cannot be) to further any biological imperative (or indeed to limit any right of succession). If so, then that purpose is advanced by UK law recognising that a couple who had lived their lives and presented to the world as a samesex couple were in fact, and for the purposes of UK civil partnership law, of the same gender. It is suggested that $A$ v. West Yorkshire Police permits the recognition of an acquired gender for the purpose of succession rights dependent upon the deceased being recognised as having changed gender. The survivor in Scenario Seven is therefore able to establish, in the eyes of UK law, the same-sex nature of the civil partnership in question, thereby satisfying $s 216(1)$, and to have the relationship recognised under the 2004 Act.

But, once again, that solution works only in its own context and not in others. It would not work if the foreign relationship were a marriage rather than a civil partnership, regarded as opposite-sex in the foreign country only because a gender change has been recognised there. If, say, New Zealand law recognises a person's change of gender and the transgendered person marries there, the New Zealand marriage would not be recognised in the UK because of the rule, analogous to s 216(1), in s 21(1) and (2) of the Gender Recognition Act 2004, which provides that a person's gender is not to be regarded as having changed by reason only that it has changed under a foreign law, and that accordingly a person is not to be regarded as being married by reason of having entered into a foreign post-recognition 
marriage..$^{90}$ As in s 216(2) of the Civil Partnership Act, it is provided in s 21(3) of the Gender Recognition Act that if a gender recognition certificate is obtained subsequent to a foreign marriage having been entered into, the relationship can be regarded as opposite-sex, validating the marriage retrospectively. ${ }^{91}$ That neutralising provision (just like s 216(2)) resolves the issue of validity of the marriage when the transgendered party is alive and able to seek a gender recognition certificate. And, as with civil partnership, if the issue arises after the death of the transgendered person (say, in relation to a question of succession) the Gender Recognition Act cannot be utilised to solve the problem. But in the case of marriage, unlike the case of civil partnership, an argument based on $A$ v. West Yorkshire Police would not be available because of the biological imperative that the House of Lords insisted in Bellinger underpins the very nature of marriage. In other words, a change of gender for the purposes of marriage (and, it may be, marriage only) can never be recognised by UK law except through the mechanism of the Gender Recognition Act. If that Act cannot be accessed because the transgendered person is dead their relationship, which was a valid opposite-sex marriage in New Zealand, will not be recognised here unless UK law finds some means of recognising what it insists on regarding as a same-sex marriage: whether this is possible is explored in Part Three below.

There is yet another problem. If, after a change of gender, a person enters into what New Zealand law regards as an opposite-sex civil partnership but UK law regards as a same-sex relationship because it refuses to recognise the acquired gender, then there would be no means of recognition under the Civil Partnership Act 2004 because the relationship is not an "overseas relationship" which by $s 212$ must be same-sex by the lex loci. ${ }^{92}$ The relationship not being recognised under the 2004 Act, the transgendered person would be regarded as single and so (if alive) entitled to seek a gender recognition certificate in the UK to have the relationship recognised as

\footnotetext{
${ }^{90}$ Gender Recognition Act 2004, s 21(1) and (2), "post-recognition marriage" being defined in s $21(5)$ as having taken place after the change of gender is recognised.

${ }^{91}$ Unless a later valid marriage or civil partnership has been entered into before the acquisition of the gender recognition certificate: $s 21(4)$.

2004 Act, s 212, as discussed above.
} 
opposite-sex - but that gets the parties nowhere since their relationship remains opposite-sex by the lex loci (and thus falls fouls of $s 212$ ) and becomes opposite-sex by UK law (and additionally falls foul of $s 216$ ). But at least in the eyes of both legal systems (and the parties) we would now have an opposite-sex civil partnership and possible solutions to the recognition of such institutions, outwith the 2004 Act, are discussed above.

\section{PART THREE: RECOGNITION OF FOREIGN SAME-SEX MARRIAGE}

The basic approach of the Civil Partnership Act 2004 is to treat overseas same-sex relationships as UK civil partnerships ${ }^{93}$ : and this approach applies both to foreign same-sex civil partnerships and to foreign same-sex marriages. For most purposes this approach renders the question of recognition of foreign same-sex marriage, ${ }^{94}$ as opposed to foreign civil partnership, unnecessary since the consequences of marriage and civil partnership in the UK are substantially similar. Nevertheless the question of recognition of same-sex marriage is not entirely superseded by the Act, for at least two reasons. First, civil partnership does not (yet?) carry the social significance and universal acceptability (even desirability) that marriage does. This idea of civil partnership as a second-rate institution in social rather than in strictly legal terms was the basis of the North American decisions opening up marriage to same-sex couples. ${ }^{95}$ Secondly, there are numerous areas in which the Civil Partnership Act 2004 creates a rule that is not identical to the equivalent rule in marriage with the result that treating an overseas same-sex marriage as a UK civil partnership is not satisfactory from the parties' point of

\footnotetext{
932004 Act, s 1(1)(b) and sched 20.

${ }^{94}$ For pre-2004 analysis of the possible approach of the Scottish court, see K Norrie, "Would Scots Law Recognise a Dutch Same-Sex Marriage?" (2003) 7 Edin LR 147. (The answer offered to that question, incidentally, was yes).

${ }^{95}$ Halpern v. Canada [2003] 225 DLR $\left(4^{\text {th }}\right)$ 529; Goodridge v. Dept of Public Health 440 Mass. 309, 732 NE 2d 1 (2003); Opinions of the Justices 440 Mass 1201, 802 NE 2d 565. Similar reasoning was adopted by the Constitutional Court of South Africa in Minister of Home Affairs v, Fourie December 1, 2005.
} 
view. Currently, ${ }^{96}$ the most important difference exists in the Scottish parts of the 2004 Act, for the Adoption (Scotland) Act 1978 has not been amended to allow civil partners the right to adopt a child jointly in the way that married couples can (or, indeed, in the way that English civil partners $\operatorname{can}^{97}$ ). A married couple from, say, Spain, will therefore be treated in the UK as married and thus able to adopt a child in Scotland if they are opposite-sex, but as civilly enpartnered and thus unable to adopt a child in Scotland if they are same-sex. The European Court of Human Rights does not yet regard that distinction within the context of adoption as in itself inconsistent with the $\mathrm{ECHR}^{98}$. A further difference between marriage and civil partnership in Scotland was created by s 3(3) and (4) of the Family Law (Scotland) Act 2006 where marriages (but not civil partnerships) are protected from invalidity on the ground of foreign formality flaws, if one or both parties is domiciled in Scotland. And another difference between marriage and civil partnership (applicable throughout the United Kingdom) concerns adultery as a ground for dissolving the union. This remains a ground for divorce, ${ }^{99}$ bringing an end to the marriage, but it is not a ground for the dissolution of a civil partnership.

\section{Scenario Eight}

Two Canadian married couples, Paul and David, and Jacob and Rebecca, come to live in the UK. David has sexual intercourse with Rebecca. Jacob can bring his marriage to an end on the ground of his spouse's adultery, because his marriage is treated as a marriage; Paul

\footnotetext{
${ }^{96}$ The Scottish Executive announced on $7^{\text {th }}$ June 2005 that Scottish adoption legislation will shortly be substantially revised and the rule prohibiting same-sex couples from adoption is intended to disappear.

${ }^{97}$ Or, presumably, Scottish civil partners travelling to England. An adoption order made by a UK court will be recognised and given effect to throughout the United Kingdom, even if made in favour of a couple domiciled in a part of the UK in which the order could not have been made in their favour: Adoption (Scotland) Act 1978, s 38(1)(c); Adoption and Children Act 2002, s 66(1).

${ }^{98}$ Fretté v. France [2003] 2 FCR 39. And indeed the same problem will arise in other European countries, where it is common to exclude adoption rights from civil partnership and marriage legislation. The Belgian legislation, for example, does not allow a same-sex married couple to adopt in that country.

${ }^{99}$ Matrimonial Causes Act 1973, s 1(2)(a) (England and Wales) and Divorce (Scotland) Act 1976, s 1(2)(a). There is an important difference in the two domestic provisions in that the Scottish provision is absolute while the English provision requires in addition that the petitioner finds the adultery "intolerable".
} 
cannot bring his marriage to an end on the ground of his spouse's adultery, because his marriage is treated as a civil partnership.

Paul does of course have the possibility of using another ground for dissolution, such as unreasonable behaviour ${ }^{100}$, but the point is that he does not have the choice, which is open to Jacob, to seek a judicial declaration that the offence of adultery has been the cause of the breakdown. The very fact that the UK legislature ${ }^{101}$ has maintained adultery in addition to unreasonable behaviour suggests that adultery is seen as something different from such behaviour, and an element to divorce law that has continuing significance. ${ }^{102}$

So, in relation to at least foreign procedural flaws and adoption in Scotland, divorce for adultery, and (as we saw earlier) recognition of foreign relationships, married couples are potentially treated rather more favourably than civil partners. The effect of the conversion of overseas same-sex marriages but not opposite-sex marriages into civil partnerships is to reveal this preference as being not for one institution over another, but for one type of couple over another. ${ }^{103}$ In other words, the law prefers (in the sense of giving preferential treatment to) opposite-sex couples as opposed to samesex couples, and that preference is open to ECHR challenge. ${ }^{104}$ There is, I $^{2}$ think, no room for doubt that all consequences of both marriage and civil

\footnotetext{
${ }^{100}$ Civil Partnership Act 2004, s 44(5)(a) (England and Wales); s 117(3)(a) (Scotland); and s 168(5)(a) (Northern Ireland).

${ }^{101}$ And, most recently, the Scottish Parliament which amended the grounds of divorce in the Family Law (Scotland) Act 2006 (by reducing the periods of non-cohabitation and abolishing desertion) but left adultery untouched.

${ }^{102}$ It is not to be thought that I am arguing in favour of extending the gender-specific and organ-specific concept of adultery into the law of civil partnership, or of creating an analogous concept to suit same-sex sexual activity outwith the bounds of civil partnership that could amount to irretrievable breakdown. Doubtless it was the impossibility of defining such activity, together with the lack of necessity to protect civil partnership from blood-line adulteration (the original essence of adultery) that persuaded the legislature that no equivalent to adultery was either necessary or desirable for civil partnership dissolution. The remedy for this difference in treatment between the two forms of conjugal relationship is to abolish adultery within marriage because it has long since lost rational (or secular) justification even within that context.

${ }^{103}$ It is this preference that is open to challenge, rather than the exclusion in domestic systems of same-sex couples from the article 12 right to marry. There may come a time when the European Court holds that article 12 requires states to extend marriage to same-sex couples, but that time is not nigh.

104 See J Murphy "Same-Sex Marriage in England: A Role for Human Rights?" (2004) 16 Child and Fam LQ 245.
} 
partnership are aspects of family life as understood by article 8(1) of the European Convention. The present paper is not the place for a full examination of the history of the European Court's evolving jurisprudence on same-sex relationships ${ }^{105}$. However, it is as well to remind ourselves of some highlights. In Dudgeon v. UK ${ }^{106}$ the Court held that a complete ban on samesex sexual activity was a breach of the right to private life ${ }^{107}$, and differential ages of consent to sexual activity between same-sex and opposite-sex partners were declared a breach of articles 8 and 14 in 2003. ${ }^{108}$ Differential treatment on the basis of sexual orientation in a custody dispute was held to be contrary to Article 8 in $1999,{ }^{109}$ and differential treatment regarding other civil rights of a same-sex couple as opposed to an opposite-sex couple in the same circumstances was held contrary to Article 8 in Karner v. Austria. ${ }^{110}$ Though it has not yet been directly asked whether treating same-sex civil partners less favourably than opposite-sex married partners is inconsistent with the ECHR, the European Court now very definitely takes the view that, just like legal differences based on sex, legal differences based on sexual orientation require particularly serious and persuasive reasons by way of justification. ${ }^{111}$

Since the conversion of same-sex marriages into civil partnerships has the effect of imposing differential treatment on same-sex couples who marry

\footnotetext{
${ }^{105}$ For further discussion, see E Johnson, "A Comparison of Sexual Privacy Rights in the United States and the United Kingdom" (1992) 30 Colum LR 697; J Liddy, "The Concept of Family Life under the ECHR" [1998] EHRLR 15; K Waaldijk "Civil Developments: Patterns of Reform in the Legal Position of Same-Sex Partners in Europe" (2000) 17 Can Rev Fam L 62; "Inching Down the Aisle: Differing Paths Towards the Legalization of Same-Sex Marriage in the United States and Europe" (2003) 116 Harv LR 2004 et seq.

${ }^{106}$ (1981) 3 EHRR 40.

107 See also Norris v. Ireland (1991) 13 EHRR 186 and Modinos v. Cyprus (1993) 16 EHRR 485.

${ }^{108}$ SL v. Austria (2003) 37 EHRR 39; L \& V v. Austria 9 January 2003; BB v. United Kingdom 10 February 2004; Woditschka and Wilfling v. Austria 21 October 2004; Ladner v. Austria 3 February 2005; HG \& GB v. Austria 2 June 2005; RH v. Austria 19 January 2006. Austria's insistence on defending these cases, notwithstanding that its relevant internal law was changed after its Constitutional Court found the differential ages of consent to be unconstitutional, illustrates that judicial policy and political policy sometimes moves at different speeds.

${ }^{109}$ Salgueiro Da Silva Mouta v. Portugal (2001) 31 EHRR 47.

110 [2003] 2 FLR 623. The facts of this case were to all intents and purposes the same as those in UK domestic cases such as Fitzpatrick v. Sterling Housing Association [2001] 1 AC 27 and Ghaidan v. Mendoza [2004] 3 All ER 411.

${ }^{111}$ SL v. Austria at para 37; Karner v. Austria at para 37.
} 
abroad as opposed to opposite-sex couples who marry abroad, the effect of the jurisprudence summarised above is that the state must provide a justifiable reason within the context of article 8(2) for making the distinction. Is the differential treatment, in other words, "necessary in a democratic society"? Does it achieve a legitimate purpose and is the rule proportionate to that purpose? It would seem clear that the purpose of the rule converting foreign same-sex marriages into UK civil partnerships is to maintain the opposite-sex character of marriage within the United Kingdom. As we have seen, the Civil Partnership Act 2004 does not permit opposite-sex couples to enter into civil partnership and the law of marriage was not changed to allow same-sex couples to enter that institution. Most countries that have introduced civil partnerships have adopted the same policy (though some, like France and New Zealand, even while maintaining marriage as an opposite-sex institution have permitted opposite-sex couples access to civil partnership). Given that this is so, it is unlikely that the European Court would hold the purpose of maintaining the opposite-sex nature of marriage in domestic law to be an illegitimate aim. But a finding that the aim of the rule is legitimate is not sufficient in itself to save it. In addition, the state must show that the conversion rule is a proportionate means of achieving that aim. The crucial question is, therefore, whether the conversion rule is necessary in order to achieve the aim of maintaining the opposite-sex nature of marriage within domestic law. I suggest that it is not, for at least two reasons. First, recognition of, and giving effect to, a foreign rule of law is not, other than in cases where public policy is at stake, normally regarded as inconsistent with the maintenance of a domestic rule of law. That proposition is, in essence, at the heart of all private international law. For example, the UK divorce law maintains a mixture of fault-based and no-fault grounds for divorce: limited grounds of divorce are seen as essential to maintain the sanctity of and importance to (UK) society of stable marriage. Yet that does not in itself justify a court in the UK from refusing to recognise a divorce based not on fault but on free consent ${ }^{112}$, or even one based on the wishes of one party and

\footnotetext{
${ }^{112}$ Cf Nachimson v. Nachimson [1930] P 217 where the argument was rejected that a relationship that could be ended by free consent was too "flimsy" to be regarded as marriage.
} 
ignoring the views of the other (such as many forms of talaq divorces). ${ }^{113}$ As well, the domestic law of the UK refuses to permit polygamous marriages on its soil or involving its domiciliaries. Yet that refusal within the domestic sphere is not compromised by the recognition (both by case law and by statute) of overseas polygamous marriages. To argue that to maintain the opposite-sex nature of marriage in domestic law requires treating same-sex marriage as something lesser is not persuasive in a country that does not argue that the monogamous nature of domestic marriage requires treating foreign polygamous marriages as something less than marriage. This is all the more so when we remind ourselves that same-sex marriage has more affinity with opposite-sex marriage as it is designed and practised today (in terms of social relationship between the parties, and the ease of the application of the existing rules) than polygamous marriage has. The second reason why the rule converting same-sex marriage into civil partnership is disproportionate is that there is no rational connection between the effects of the conversion rule and its legitimate aim. To deny adultery as a ground to dissolve a same-sex union, or to allow the ignoring of foreign formalities in marriage ceremonies but not civil partnership registrations, or to limit adoption to opposite-sex couples does not itself advance any interests of opposite-sex unions: it merely preferences them. These differential effects do not advance the aim of maintaining the opposite-sex nature of marriage: they simply penalise those who enter a marriage that is not opposite-sex.

For both these reasons, it must follow, in my view, that the conversion rule under which foreign same-sex marriages are treated not as marriage but as civil partnership, thereby discriminating between same-sex and opposite-sex

\footnotetext{
${ }^{113}$ Grounds for recognising foreign divorce are contained in Part II of the Family Law Act 1986 (and equivalent rules for recognising foreign dissolutions of civil partnership are contained in Part V, chapter 3 of the Civil Partnership Act 2004). In addition, arts 21 et seq of the Brussells Ilbis Regulation (EC Reg 2201/2003) ensure the automatic recognition of divorce judgments obtained within the EU. It is unclear whether this Regulation can be interpreted to include the dissolution of civil partnership (or of same-sex marriages from the Netherlands, Belgium or Spain) but in any case s 219 of the Civil Partnership Act 2004 allows for the making of (domestic) regulations to correspond with the rules in Brussells llbis, a power exercised with the Civil Partnership (Jurisdiction and Recognition of Judgments) Regulations 2005, SI 2005/3334 (December 1, 2005) and the Civil Partnership (Jurisdiction and Recognition of Judgments) (Scotland) Regulations 2005, SSI 2005/629 (December 1, 2005).
} 
couples, is disproportionate to the aim of maintaining the UK's conception of marriage as an opposite-sex institution. As such, the differential consequences of doing so are, I suggest, inconsistent with arts 8 and 14 of the European Convention on Human Rights.

\section{PART FOUR: CONCLUSION}

It is in my view entirely right and proper that the rules for civil partnership do not completely replicate those of marriage, for some rules will be inappropriate or fail to address different needs, expectations and circumstances of the two types of couple. ${ }^{114}$ So the question becomes whether the different international environment between state-sanctioned same-sex relationships and state-sanctioned opposite-sex relationships justifies such different private international law rules as have been identified in this article.

The major international difference between marriage and civil partnership is the universality of the former compared to the territorial limitations of the latter. Personal capacity will not arise as a realistic question in jurisdictions with no concept of civil partnership ${ }^{115}$ and for that reason we may conclude that it is legitimate to refer capacity to the lex loci registrationis rather than the personal law, which may be silent on the issue. However, the application of UK rules of eligibility to all those domiciled in the UK - and to their prospective partners - no matter where the partnership is registered does not reflect any international necessity but amounts to no more than the application of parochial UK law in place of a foreign rule of law. Of course UK marriage law applies, in both formalities and many aspects of capacity, for marriage within the UK and insofar as that is justified the same rule for civil partnership cannot be criticised for being discriminatory. But to apply UK law in the matter

\footnotetext{
${ }^{114}$ See the examples in $\mathrm{n} 9$ above. I have previously warned against the dangers of assimilation posed by the campaign to open up an undifferentiated form of marriage (designed by and for the heterosexual majority) to same-sex couples: see "Marriage is for Heterosexuals: May the Rest of Us be Saved from It" (2000) 12 CFLQ 363.

${ }^{115}$ See $\mathrm{n} 52$ above and accompanying text.
} 
of legal capacity (at least in relation to nonage) to foreign partners of UK domiciliaries in relation to partnerships created abroad is unprincipled and, in Scotland at any rate, discriminatory since that approach does not apply in marriage. In addition, the whole process of converting foreign same-sex marriages into domestic civil partnerships is a disproportionate response to a domestic political imperative which serves only to confuse personal relations and complicate family life in the international context.

Gaps in the legislation are, perhaps, inevitable. After all, the issue of recognition of foreign (opposite-sex) marriage has been one of the most fertile sources of litigation in private international law and it is not, therefore, surprising that every possible scenario relating to civil partnership cannot be resolved by a universal rule. But it would be a grave (and unsustainable) mistake to assume that foreign same-sex (and opposite-sex) civil partnerships and same-sex marriages are either recognised under the Act or they are nothing. As explained above, there remains room for the common law to perform its traditional role of filling the gaps - there will indeed be no alternative when the court is faced, as inevitably it will be, with relationships that are neither marriage nor "overseas relationships" as narrowly defined in the Act. Given the variety of family forms, and the levels of population mobility, in the modern world such questions are likely to arise sooner rather than later. The development of same-sex relationship recognition in the domestic sphere, by challenging long-held preconceptions of family life, gives us the chance to rethink relationship recognition in the international sphere. The challenge is to identify when it is truly appropriate to apply a different rule to different forms of relationship, free from the all or nothing assumptions surrounding traditional marriage. The Civil Partnership Act 2004 was the most significant advance in LGBT equality since the decriminalisation of (male) same-sex sexual activity. The message from Parliament was clear and it is now for the courts to build upon that advance and to develop the existing rules and principles both in statute and at common law to ensure that same-sex couples whose relationships are legally created abroad are recognised or not in a way appropriate to their diverse circumstances, and are 
not subjected to any more complicated regulation of their family lives than opposite-sex couples in analogous circumstances.

Kenneth McK. Norrie

Professor of Law and Head of the Law School, Strathclyde University

The helpful comments of the following individuals are gratefully acknowledged, but responsibility for any expression of opinion and for any error remains mine alone: Mr John Murphy, University of Manchester; Dr Kees Waaldijk, University of Leiden. 